HUMANIKA Vol. 19 No. 1 (2014) ISSN 1412-9418

Hadrami Diaspora In Karimunjawa

Rabith Jihan Amaruli

\title{
HADRAMI DIASPORA IN KARIMUNJAWA: Between Identity Maintenance and Assimilation
}

\author{
Rabith Jihan Amaruli \\ History Department-Faculty of Humanities, Diponegoro University \\ J1. Prof. H. Soedarto, SH Tembalang Semarang 50275 \\ Email: rabith_jihan@yahoo.com
}

\begin{abstract}
This study discusses the Hadrami diaspora in Karimunjawa, between identity maintenance and assimilation. Through oral history, this study found that the coming of Hadrami in the early 20th century in Karimunjawa was solely motivated for economic reasons. They -lived and improved their quality of life by working as laborers in the Chinese traders. The economic limited access caused Hadrami in Karimunjawa were not played an important role both in economic and Islamic teaching. For economic reasons as well, their numbers had dwindled in the mid of 1990 s20th century. Most of them moved to Semarang and Jepara while the small group still survived in Karimunjawa. As a sayyid family, the Arabs in Karimunjawa did intermarriage mixed marriages (between sayyid and non-sayyid). The role of the Arabs in Karimunjawa was begun from Sayyid Abdurrahman era whose became the new icon of the Majelis Al-Khidmah, a teaching institution based in Surabaya. Recently, it has branches in many parts of Indonesia.
\end{abstract}

Keywords: diaspora, Hadrami, identity, assimilation

\section{BACKGROUND}

This study began from my involvement when I conducted Social Research Methods course at Department of History, Faculty of Humanities, Diponegoro University in Karimunjawa islands. At the same time, some reasearch counterparts and I were-was also involved in research project of maritime ethnic acculturation in Karimunjawa islands. ${ }^{1}$

${ }^{1}$ I should say thank to Mahendra P.udji Utama and A. Dwihendrosono ( $\dot{A})$ for our a great discussion whenile we stayeded in Karimunjawa. Some important inputs related
In that process, I met with Sayyid Abdurrahman Al-Hamid, a Hadrami descent who had long lived in Karimunjawa. The meeting made me interest to explore more about Hadrami in Karimunjawa. Writing

to migration, ethnicity, and social integration in Karimunjawa are extremely useful for this study. My special thanks to Mahendra Pudji-P. Utama whosefor gaveiving me some important references about ádiasporaô Last, As an amateur in English writing, I should say thanks to Noor Naelil Masruroh for her kindness to read and correct and fixed this article.
Comment [WU1]: Bapak, how about if we use term of "intermarriage"? 
HUMANIKA Vol. 19 No. 1 (2014) ISSN 1412-9418

Hadrami Diaspora In Karimunjawa

Rabith Jihan Amaruli

about Hadrami in Karimujawa is interest, considering Sayyid Abdurrahman is one of Hadrami Arabs whoôs still óremainsô in the mid of Karimunjawa multiethnic society.

Karimunjawa as a multiethnic society appears of the ethnic compositions that has stayed, settled, and inhabited in the islands, i.e.: Java, Madura, Bugis, Mandar, Bajau, and Buton. The administrative center located in Karimunjawa village-, which is also become the research location. The village shows that Javanese are the majority of the population. Although derived from various ethnics, the social life in Karimunjawa is closer to Javanese life. It can be seen from the type of brick houses, traditions, and their daily language. It is very easy to find people who speak Javanese fluently, whatever their ethnicity. It is why, the ethnic origin who are inhabitted of the islands can not be identified easily. The ethnic compositions in Kemujan village, the closest village from Karimunjawa administrative center, are revealing a different face. In Kemujan, especially in Batulawang, which has become Bugis community in Karimunjawa, we will easily find Bugis houses on stilts that stands in the amidst of the mangroves and reeds. We will find a lot of people speaks Bugis than the Javanese, although Javanese language is not an obstacle for them.

The ethnic population in Karimunjawa also consists of two foreigners ethnic, they are Chinese and Arabs. Since the colonial period, the Chinese and the Arabs had been existed and demonstrated their existence in Karimunjawa. The Chinese economy activities played an important role regarding to coconut plantation, especially copra as a leading commodity. The Chinese introduced the first grocery stores, pawn shops, and mortgagees the lending of capital to society. Controlling over the important of economic access had made the Chinese as the rich man. Most of them used his wealth to lured girls to be concubines (Interview with Asrini, June 4th 2013). She was well-known as an elder and baby masseur. Her father, Mulyani, was a police officer in the Dutch colonial period. The Chinese in Karimunjawa derived from Lasem, Jepara, and Semarang. Uncommonly, when they came to Karimunjawa, the Chinese traders carried laborers (workers) from their regions. Some of the workers are Arabs (Interview with Asrini June 4th 2013; Sayyid Abdurrahman, June 2nd 2013).

In the Post-colonial period, the ethnic composition in Karimunjawa gradually changed, the Chinese who previously played an important role in the economic, they leaved Karimunjawa when the Japanese occupation. Ba Kin Ting/ Ba Ging Sing for example, a wealthy merchant of copra, decided returned to Lasem and died there. It was confirmed in 1965. Many Chinese leaved Karimunjawa in the Post-G30S. For the Chinese who remained in Karimunjawa, decided to change their name and religion based on the governmentôs insistence. Hong Tek, for example, was one of the five wealthy Chinese merchants in Karimunjawa, decided to stay in Karimunjawa. $\mathrm{He}$ became moeslemMoslem and changed his name to Widodo. His ability in writing became the reason why he was
Comment [WU2]: May I say that one of Chinese activities were "mortgagees"? --> orang yang sering ngutangi Pak. 
HUMANIKA Vol. 19 No. 1 (2014) ISSN 1412-9418

Hadrami Diaspora In Karimunjawa

Rabith Jihan Amaruli

selected to be Carik (village secretary). Up now, there are only two identifiable Chinese families in Karimunjawa (Interview with Asrini, June 4th 2013).

For different reasons, the Arabs Hadrami began to leave from Karimunjawa (Interview with Martoyo, June 4th 2013). There are two Hadrami clans who still remain, namely Sayyid Abdurrahman in Karimunjawa and Faisaluddin in Kemujan. This study intends to reveal the existence of Hadrami in Karimunjawa followed by the main questions. What is the motivation of Hadrami arrived in Karimunjawa? How are they maintains of their existence in the multiethnic society of Karimunjawa? What are the taken options for them to maintain their identity or assimilate? The answers of these questions are expected to provide a comprehensive understanding about the existence of Hadrami in Karimunjawa.

\section{METHODOLOGY}

The Hadrami existence in Karimunjawa can be analyzed by using concept of diaspora. The diaspora is derived from the two word ancient Greek namely dia (áhroughô) and speirein (ópreadô or óowô. Diaspora refers to sociological concept of trans-national and trans-cultural. It is about the displacement of inhabitants in the territory or region of their culture, accompanied by the formation of cultural identity in a new place with oriented to cultural origin. Originally, the concept of diaspora used to see the context of transnational migration. However, in its development, the people displaced from one area to another within a specific region or territory, it may also be included in the diaspora category (Ember, Ember, and Skoggard, 2005: xviii; See also Hall, 2006: 475). Based on the most prominent reasons, the diaspora can be divided into five types, i.e. victim, labor, trade, imperial, and cultural diaspora. The emerging types of diaspora are motivated by changing definitions of it and the symptoms as the reference (Cohen, 1997: ix-x).

In that context, Hadrami diaspora can be placed in to trade and labor diaspora. Practically it caused all Hadrami immigrants evolved the trade and labor. In fact, the typical of newcomers of Indonesian Hadrami in the late 19th century was worked as shop assistants or small traders which referred to their who had been a resident in the archipelago (Kesheh, 2007: 15). After received salary, they became as like as the number of independent Chinese traders. Most of them -would be middleeconomic brokermen by buying import goods from the European firms and reselled it to other dealers or consumers in Indonesia (Kesheh, 2007: 16). Since his arrival, Hadrami could be integrated easily with the locals. They had been thoroughly assimilated with the indigenous in three or four generations. The main factors were that the majority of immigrants were men. There were fairly high intermarriages between Hadrami and native women (Berg, 2010: 33). Now, these conditions generate two groups of the Hadrami immigrants in Indonesia, namely walaiti (original) and muwallad (hybrid). By the immediate results of the Hadrami hybrid descent diaspora made them to 
become the majority group of their community (Kesheh, 2007: 18).

Traditionally Hadrami divided into a complex social stratification system affects almost every aspect of life, including their employment. The social division enforced Islamic legal principle (kafaah), for example, the women are only allowed to marry with men who have equal or higher of social status. The highest class in Hadrami is sayyid, the social elite groups who claim to be a direct descendant of the Prophet Muhammad Pbuh, especially from his grandson Husayn. On the basis of the sayyid, they respect as Islamic teacher, and kind of mediator in tribal disputes. Some sayyid even considered to have supernatural powers. The famous sayyidê tomb is considered sacred and popular place to do certain activities such as pilgrimage (Kesheh, 2007: 2122).

Beside sayyid group also known as the non-sayyid. Those Arabs who fall into this category is masayikh (scholar), qabail (tribal chief), masakin, and dhuafa (the poor). The masayikh and qabail sometimes have same religious role, although they remain lower position from the sayyid, while masakin is large groups which are includes of merchants, artisans, artists, followed by dhuafa people. Although it has maintained in Indonesia until the 20th century, but Berg observed that it had collapsed in the late 19th century. According to him, became a sayyid did not guarantee a higher status (Berg, 2010: 23).

Social, political, economic, and different cultural conditions requires them to make important changes both in social stratification, integration, economic dynamics, and even in their socio-religious life reform. In this context Hadrami immigrants are faced two important choices between maintaining their identity or assimilation. The question about Hadrami identity maintenance become become a great debate today. This is because the Hadrami has played between two identities, they must assimilate into indigenous community as a process and to maintain their status as the taken results of cultural values, one of which is maintaining nasab (lineage) (Abushouk and Ibrahim, et. al., 2009: 9). The issue of sayyid and non-sayyid can be an example of this phenomenon, because the lineage for the Hadrami is not only merely cultural but also religious issues. However, the issue of sayyid and non-sayyid canâ -be understood with the organization or a particular theological concept. It $\hat{Q}$ religious dynamics associated with social and economic factors among Hadrami, as well as the broader stratification, political, and economic position system, etc. (Manger, 2010: 12).

This study is examined by oral history method. It is selected because it is one of the most suitable method to describe the existence of the Arabs (Hadrami) in Karimunjawa which is lack of sources including the supported documents. The oral history method is also very suitable for work in writing of local history which also has a similar problem. Because more personal, local, and unofficial documents, so it hard to survive (Thompson, 2012: 3). As a result, the lives of ordinary people, for example, who barely received attention in official government records, -will be pass by the time. Therefore, oral
Comment [WU3]: Bapak, where is the
sentence refer to? Especially "they hard to survive". 
HUMANIKA Vol. 19 No. 1 (2014) ISSN 1412-9418

Hadrami Diaspora In Karimunjawa

Rabith Jihan Amaruli

history as one of the method to explore

the ordinary people experiences-, overcome the limitations of the written documents which are not many and often not well maintained. The oral history also can highlight a few episodes of a dark and mysterious history (Roosa and Ratih via Nordholt, et. al., 2008: 177). The materials in the oral history are the experience of peopleâs life. It is provide closely to the resemble sources, which basically published in autobiography, only in a broader scope (Thompson, 2012: 5).

The main problem is the writing through oral history becomes very subjective. Therefore, to conduct oral history, the historian must do what is called óvorking throughô their connection with the emotional response of the people who interviewed for. The óvorking throughô is a continue process to reexamine assumptions that have been ingrained in us, to check what we think is reasonable, or to view what we control, therefore it will not to appear on the surface (Roosa and Ratih via Nordholt, et. al., 2008: 180).

\section{RESULT AND DISCUSSION}

\section{A. Karimunjawa as a multiethnic society: a sesiesocio-cultural view}

Karimunjawa is a typical of multi-ethnic society marked by the existence of some ethnic groups including Java, Madura, Bajau, Bugis, Buton, and Mandar. There are many Bugis people whose still builds homes | by using-stage, the Buton and Bajau prefer to stayed around at the beaches in Karimunjawa. Meanwhile, the Javanese and Madurese existences are common in Karimunjawa, therefore inter-ethnic meetings intensity is so high. Many interethnic marriages are performed, resulting in a hybrid generation who lived and settled in the islands. The massive migration waves occurred during the 1950s from various regions of Central Java, Madura, Masalembu, and Sulawesi to Karimunjawa Islands. In the new area they lived in some parts of the islands, since the early 1980s Karimunjawa village/island became autonomous villages, follwed by the other villages such as Kemujan, Parang, Nyamuk, and Genting, which defined as part of the Karimunjawa islands sub-district.

The migrant from Central Java, particularly from Jepara, has become a part of Karimunjawa population since Dutch colonial era. In this period the Chinese had an established position in Karimunjawa village. They played an important role in copra plantations and its trading. They also opened the first grocery stores in the village. Mastery over the most important economic areas put the Chinese as the rich. Most of them use their economic wealth to lured women to serve them, the women were so-called to be Javanese mistress (gundik). Most of the Chinese in Karimunjawa migrated from Semarang. When they came to Karimunjawa, they brought the Arabs to help their trade. That is why, until now there are -also Arabs descent in Karimunjawa. Based on the information, until 1960ô there were a lot of Chinese who lived and died in Karimunjawa. They were buried in the villageôs grave. Unfortunately, the evidence of their presence has lost and destroyed by the irresponsible hands.

Since the end of the Dutch colonization, the composition of 
Karimunjawa population began to change. Most of the Chinese leaved the islands during the Japanese occupation for security reasons. The Chinese immigrant increasingly shrinking after G30S 1965. Only a few people who decided to live in Karimunjawa and later they changed their -names and converted to Islam (Interview with Asrini, June 5th 2013). With economic reasons, since the 1990s, Arabs in Karimunjawa has also leaved from the islands. The conditions caused shrinking in number of Chinese and Arabs. Until today, there are only two Chinese and Arabs families that can be identified in Karimunjawa. One-One of them lived in Karimunjawa and another in Kemujan.

Although the majority of religious adherents in Karimunjawa are MuslimMoslem, Karimunjawa is a pluralistic society seen in terms of religion. Since the late 1960ô in the Karimunjawa village began to grow Christian community. Their presence in Karimunjawa might had ttakeaken place long before the 1960s by Dutch and Chinese influences. Along with their departure during the Japanese occupation, the number of Christians decreased drastically (Interview with Pastor Matius Slamet, June 4th 2013).

In fact, although Christianity has gained a well-established position, characterized by the presence of two Pentecostal Church, built in 1968 in Karimunjawa and 1990s in Kemujan, the Christians remain a minority. Until 2010 they only could be found in two villages. In Karimunjawa, 4,446 residents are only 42 Christians consisting of 15 Catholics and 27 Protestants. In Kemujan, from 2,750 populationpeople, only 18 people of them are Christians and they were entirely Protestant. Most of the Christians in the late 1960s to 1970 s are civil servants. They assigned in civil workers and military agencies, most of them came from the outside of the islands. In order to serve worship congregation and social activities, the Council of Indonesia Chruch commissioned a priest in Karimunjawa (Interview with Pastor Matius Slamet, June 4th 2013).

\section{B. The first Arabs generation in Karimunjawa}

It is hard to determine who-is $\underline{\text { se }}$ the first Arabs in Karimunjawa. The story states that the Sayyid Abdullah whose tomb is in Kemujan village is the first Arab in Karimunjawa- In fact, he cited figures predate the leading before Islamic preacher, MMoenMostenenim missionaries in KarimunjawaSunan Nyamplungan.

Regarding the figure of Sayyid Abdullah, there is no complete and definitive information. The only information obtained is come from the story of the Village Chief officer of Kemujan, H.M. Yuslam Said, he got the information based on his spiritual meeting with Sayyid Abdullah. According to Yuslam, Sayyid Abdullah was a propagator of Islamic leader that coming from Gujarat, India. His wife was a daughter of Chinese descent who came from Palembang. During Islamization, Sayyid Abdullah and his wife worked as a draper. Yuslam was not mention exactly when he came to Kemujan, he just said that the life span of Sayyid Abdullah was standing before the Demak Kingdom, the first Islamic kingdom in Java. His desire to meet Sayyid Abdullah must
Formatted: Font color: Red, Indonesian (Indonesia)

Formatted: Font color: Red, Indonesian (Indonesia)

Formatted: Font color: Red, Indonesian (Indonesia)

Formatted: Font color: Red, Indonesian (Indonesia)

Comment [WU4]: Pak, apa maksud ini?
kalau yang dimaksud dalam bahasa
Indonesia adalah angka tahun di nisan
Sayyid Abdullah lebih tua dibandingkan
dengan angka tahun di nisan Sunan
Nyamplungan ---> The written year figures
on Sayyid Abdullah headstone is older than
the figures on Sunan Nyamlpungan.
Formatted: Font color: Red,
Indonesian (Indonesia)
Formatted: Font: (Default) Times
New Roman, 12 pt, Font color: Red,
Indonesian (Indonesia)
Indonesian (Indonesia) 
HUMANIKA Vol. 19 No. 1 (2014) ISSN 1412-9418

Hadrami Diaspora In Karimunjawa

Rabith Jihan Amaruli

be followed by reading Quran. Hence the practice of recitation of the Quran is the most favored by Sayyid Abdullah. Whoever visits to his tomb for ziarah (pilgrimages) or attends event of Sayyid Abdullah Haul, are suggested to read the Quran (Interview with H.M. Yuslam Said, June 6th 2012).

This information may be difficult accepted by scientific logic, but it confirms of the important position of Sayyid Abdullah in the community. Some information from several religious figures in Karimunjawa stated that Sayyid Abdullah was merchants and scholars propagator of Islam, the Prophetôs descendants named Al-Attas | (Interview with Sayyid Abdurrahman, June 2nd 2013; Interview with K.H. Abdul Muin, June 5th 2013). This titleIt -is reminiscent of the title used by the original sayyid whose comes from Hadramaut. In addition, some of the pilgrims who visits the tomb of Sayyid Abdullah Al-Attas derived from Singapore and Malaysia, so it becaeeme the interesting facts.

If we agree of -with Bergôs opinion that the Walisongo (the nine

MoesleamMoslem missionaries), primarily Sunan Kudus, is a descendant of Al-Imam Ahmad ibn Isa Al-Muhajir, the ancestors of sharif of Hadramaut sayyid in the archipelago, the next Hadrami Arab descent in Karimunjawa is Sunan Nyamplungan or Amir Hasan (Berg, 2010: 175).

| Another_sources mentions that Amir Hasan is a son of Sunan Kudus who I later became adopted son byef Sunan Muria. Like his ancestor, Syeikh Amir Hasan or Syeikh Murti, later known as Sunan Nyamplungan transformed into a staunch propagator of Islam in
Karimunjawa. The toponymic legend of some areas in Karimunjawa (like Legon Lele, Cik Mas, Nyamplung Ragas, Legon Boyo, etc.) in Karimenjawa are always associated with Sunan Nyamplunganôs figure. In fact, the myths behind the Edor snake, which is endemic fauna in Karimunjawa is also associated by the sacred (Interview with Sutrimo, June 5th 2012 . He is Karimunjawa village elders, Javanese). It shows that the position of Sunan Nyamplungan is very important for socio-religious life of the community. His grave is always crowded with pilgrims every Monday and Thursday, they are just visits, asking the blessing from Sunan, or even pay their nazar (vows). The AuslimMoslem believes that ignoring nazar will be bad for their future life (Interview with Andi Bugis, June 6th 2012. He lived in Batulawang, Kemujan, Bugis).

To the right of Sunan Nyamplunganôs tomb, there is also tomb of Sayyid Abdullah_(different with Sayyid Abdullah in Kemujan), but there is no adequate information about this figure. In addition, the title of Al-Attas listed in the tomb, however there is no obtained confirmation of the validity of this figure. Aside from Nyamplungan, the tomb of Sayyid Abdullah also can find in -in the common grave of Karimunjawa village. Interestingly, this latter Sayyid Abdullah is also has title of Al-Attas. Apparently, Sayyid Abdullah is the last top generation-Al-Attas generation in Karimunjawa. It is not clear where is Sayyid Abdullah came from. Based on information from elder villagers, Sayyid Abdullah was newcomers and lived in Karimunjawa village mosque. He spent time to worship of the God 
and took care of the mosque. He died at a young age without leaving wife and children. The sacred figure touted as evidenced by the light rays coming out of his grave for a few days after his death (Interview with Asrini June 5th 2013). The next Arabs Hadrami generation in Karimunjawa is the family of Al-Hamid started by their ancestors Sayyid Muhammad AlHamid from Semarang.

\section{The $20^{\text {th }}$ Hadrami generation in Karimunjawa: between identity maintenance or assimilation}

Al-Hamid is one of many Hadrami clans which are found in Indonesia, in addition to Al-Attas, AsSaggaf, Al-Haddad, Al-Habsy, and others. As a family of Hadrami Arab descent, Al-Hamid clan is in the sayyid category, the first class of the social structure of Hadramaut groups. They are descendants of Husayn, a grandson of the Prophet Muhammad Pbuh. They get a degree Habib (for men), and Hababah (for women) (Berg, 2010: 33). Only in their home country, habib has an important position in socio-religious life of the Indonesian people, especially among Moeusleaim traditionalists.

According to the story, a character whose first earned nickname (title) $\tilde{n}$ Alhamidò is Waliyyullah (saint) called Al-Hamid Al-Syaikh ibn Abi Bakr ibn Salim ibn Abdullah ibn Abdurrahman ibn Abdullah ibn AlImam Abdurrahman As-Saggaf. AlHamid title bears based Arabic, the meaning of hamid is a person who always be grateful for all the blessings given by Allah Swt.- According to the meaning, it cause Al-Syaikh Salim ibn Abi Bakr gives the name of one of his children with Al-Hamid, he wish that his son can be the one to always be grateful for all the favors, given by God, either in a state of love and grief (http://ahlulbait.blogdetik.com/2009/0 1/22/marga-al-hamid-3/, downloaded on July 19th 2013).

Al-Hamid was born in the city of Inat, and blessed by five sons each named: 1) Muthahhar, which is a descendant of Al-Hamid ñAl-Aqil Muthahharò of his son named Aqil ibn Muthahhar; 2) Omar, who became AlHamid offspring, ñAl-Salim ibn Omarò, from his son Salim ibn Omar. This figure much gave the descendants of Al-Hamid primarily located in Indonesia; 3) Abdullah; 4) Abu Bakr, and 5) Alwi, each offspring are mostly located in Hadramaut. Al-Hamid ibn Syeikh Abi Bakr passed away in the city of Inat in 1030 Hijriyyah (http://ahlulbait.

blogdetik.com/2009/01/22/marga-alhamid-3/, downloaded on July 19th 2013).

Based on the research, clan of Al-Hamid, who is the first come to Karimunjawa is Sayyid Muhammad Al-Hamid from Semarang. It is not surprisingly, because Semarang become-became one of the centers and important Hadrami Arab colony in the northern coast of Central Java beside Pekalongan. In the early of the 19th century, the arrival of the Arabs in Semarang, aimed to tempt fate in trading. Despite trading, there were also Arabs who became religious advisor and tabib (Kroef, 1953: 305 via Fitriyana, 1987: 39). They came to Semarang not as large traders, but as small merchants. Usually, they were also involved in import-export trade activity. The arrival of the Hadrami who was came -from Hadramaut by
Comment [WU5]: Pak, maksudnya yang ke-20? 
HUMANIKA Vol. 19 No. 1 (2014) ISSN 1412-9418

Hadrami Diaspora In Karimunjawa

Rabith Jihan Amaruli

invitation of their relatives in Semarang. Hence, these newcomers did not have difficulty to venture capital and life in the colony. It cause that the Arabs in Semarang generally comes from the same place in Hadramaut.

Since 1870 steamship voyage between the Far East and the Arab experiencing rapid development. So | that the migration of Hadramaut to Indonesia was become easier. In 1885 , the number of Arabs in Semarang reached 673 people, while the number | of Arabs in Jepara reached 77 people. From that numbers, the Arabs generally were born in the archipelago

| (Berg, 2010: 96). They lived in the coastal areas which are then transformed into an important Arab colonies stretching from Palembang, Batavia, Cirebon, Pekalongan, Semarang, Surabaya, and Gresik. The | Arabs colony in Semarang was older, as old as in Pekalongan. In 1819, the Arab colony in Semarang was old enough led by the head of the colony. At the span time between 1840 and 1855, some Arabs would accumulate large capital and wealth that can be enjoyed by their children and grandchildren. However, there wew were many impoverished Arabs. Some of them were -raised -economically by marrying the rich native women. In

| Semarang, the Arabs were not has their own territory. They settled in the Malay region which also accommodated the Chinese. There was also a mosque to daily praying which was built by the Arabs (Berg, 2010: 106). Although economic motives, the trade was so thick in the life of the Arabs, the other motives were such as of Islamization, it could not be considered trivial. Many Arabs later became religious advisor, teachers, and even be a healer. While they were falling into poverty, should try their fortune, working on the rich merchants, including Chinese.

In this context, Sayyid Muhammad Al- Hamid followed by one of the wealthy Chinese merchants in Karimunjawa. There is no sufficient information when and where Sayyid Muhammad was born. The A conclusive information about Sayyid Muhammad Al-Hamid was his original that he came from Kampung Kuningan, Semarang. There is also no definitive information about when Sayyid Muhammad Al-Hamid came to Karimunjawa. By speculate intention, since young he migrated to Karimunjawa and became an assistant in a grocery store owned by a Chinese. According to Sayyid Abdurrahman AlHamidôs calculation, one of the sons of Sayyid Muhammad Al-Hamid who currently lives in Karimunjawa, in 1930s was likely her father arrival to Karimunjawa (Interview with Sayyid Abdurrahman, June 2nd 2013). Sayyid Abdurrahman Al-Hamidô calculation is perhaps true. It is remembering that 1930s were periods of deterioration in the economics of the Arabs in Semarang due to the economic crisis. The results of production could not be marketed, particularly export crops such as tea, sugar, coffee, rice, and perfumes. Therefore the Arabs trade commodities in Semarang limited -of leather, copra, and batik. In addition, there were many Arabs who became moneylenders. It was also caused by shortage of regeneration efforts among Arab families in Semarang (AlDjoefri, 1938 via Fitriyana, 1987: 71).

A few years after he lived in Karimunjawa, Sayyid Muhammad 
HUMANIKA Vol. 19 No. 1 (2014) ISSN 1412-9418

Hadrami Diaspora In Karimunjawa

Rabith Jihan Amaruli

married a Bugis woman named Asiyah. From this marriage, Sayyid Muhammad endowed five children, namely Rugaiyyah, Elok, Thohir (died when he was child), Fatimah, Nur Khalijah, and Mukhsin (now he stays in Jepara). After his first wife died, Sayyid Muhammad married again with the native female, named Amirah. From that second marriage, Sayyid Muhammad gained a son named Abdurrahman Al-Hamid, Al-Hamid generation successor in Karimunjawa (Interview with Sayyid Abdurrahman, June 2nd 2013). A year after the birth of Abdurraham, Sayyid Muhammad died. He was buried in a Karimunjawa common grave near to the tomb of Sayyid Abdullah Al-Attas. Some people believes that the sayyid family has a distinctive feature. The family some of the features that distinguish from other family is the-believesf that if the wife bear a boy then, the mother would die soon. Some people alsoThey also believe that the body of a sayyid will not rot because guarded by Allah. It was supported from the statement of Asrini. She said that the relatives of Sayyid Muhammad whoôs from Semarang can converse with the tomb of Sayyid Muhammad in Arabic (Interview with Asrini, June 5th 2013).

Sayyid Abdurrahman Al-Hamid was born in Karimunjawa in 1941. A year later, his father died. Because of the economic conditions that are no longer of life improvement, all his children of the first wife of Sayyid Muhammad decided to move from Karimunjawa to Kampung Kuningan following their relatives in Semarang. Sayyid Abdurrahman decided to stay in Karimunjawa because he has a mother in Karimunjawa. Like other children, Sayyid Abdurrahman completed primary education in Karimunjawa. After finishing his primary education, he continued to secondary education at the junior secondary school (madrasah), also in Karimunjawa. Unlike when he underwent primary education that was filled by a non-religious subjects, Sayyid Abdurrahman deeply enjoyed of his secondary school in madrasah which was provide more servings of religious subjects, especially Arabic.

He was so very enjoyed Arabic subject and always got high mark compared to his other friends. Therefore, after completing the madrasah, he won a scholarship to continue her education in Madrasah At-Thohiriyah Tanah Abang Jakarta. He studied and sharpened his ability in Arabic to the Egyptian scholars, Sayyid Ahmad. In Jakarta Sayyid Abdurrahman met Nur Zain, a man from the Seribu Islands which later became his adoptive father. In Madrasah At-Thohiriyah, Sayyid Abdurrahman showed satisfactory progress. Madrasah recommend him to continue his education in Medina. Therefore required to pay IDR 60,000 as registration requirements, whereas his adoptive father in Seribu Island did not provide an answer to pay the registration fees, he then discouraged (Interview with Sayyid Abdurrahman, June 2nd 2013).

After completion his education in Madrasah At-Thohiriyah in 1961, he returned to the business in Karimunjawa by selling timbers. At that time, his market area was Karimunjawa to -Semarang. The intensity round transportation between Semarang and Karimunjawa then introduced him to Al-Habib Lutfi ibn Yahya, a sayyid who nowadays
Comment [WU6]: Pak apakah ini artinya Bahasa Arab? 
HUMANIKA Vol. 19 No. 1 (2014) ISSN 1412-9418

Hadrami Diaspora In Karimunjawa

Rabith Jihan Amaruli

become one of the charismatic leader

| from Pekalongan. On that time, AlHabib Lutfhi ibn Yahya is still actively running the cloth business. In a tone of humor, Sayyid Abdurrahman said: ñpreviously, Luthfi has black skin, like me, because he often heated by sun. Recently he has white skinò (Interview with Sayyid Abdurrahman, June 2nd 2013). Its proximity to Al-Habib Lutfi ibn Yahya gives a deep impression. Sayyid Abdurrahman stated that Lutfi is was the one of thewho has sponsored s for him to be appear to be an Islamic leader in Karimunjawa. ñAl-Habib Lutfi said, Habib Abdurrahman never come out from Karimunjawa. Karimunjawa people must have habibò, said Sayyid Abdurrahman.

Sayyid Abdurrahman was first married in 1963 to a native woman named Hanifa. From his marriage he gained three children, namely Mirâtus Saĉdah, Nur Habibah, and Bastaan Banani. After Hanifaôs death, Sayyid Abdurrahman married again with local woman, named Temi. He gained only | a son from his second marriage-, named Faisaluddin. A few years, after the death of Temi, Sayyid Abdurrahman married to Siti Muasarah. From his marriage with Javanese woman he gained a daughter named Lailatul Fajriyah. The AH children of Sayyid Abdurrahman from the his first wifemarriage, ${ }_{2}$, liveding outside of Karimunjawa Islands, especially in Jepara and Bawean. His last son, Faisaluddin works as a sand miners and he lived in Kemujan, while his last daughter stayed with him in Karimunjawa.

As a Mostem-Moslem and sayyid, Sayyid Abdurrahman is more pleasure giving their children names with the Arabic rather than Javanese name, such as Endang or Bambang. According to him, the Javanese name feels less solid and less Islamic. Sayyid Abdurrahman also provide Arabic name for people who ask for naming their child, such as Muhammad, Bahr Ulum, Fatimatus Zahra, etc. In terms of music as his hobbies, Sayyid Abdurrahman prefer Shalawatan and Gambus Arabic, for example the shalawat are recited by Al-Habib Syaikh ibn Abdul Qadir AsSaggaf from Solo., playing Al-Habib Syaikhôs CDs and cassetes widely circulated in Java including Jepara and Karimunjawa.

Although Sayyid Abdurrahman understand that marriage between hababah (woman sayyid) and nonsayyid can damage the family áreeô (lineage), he does not object to her daughterôs decision to marry with -a non-sayyid. According to him, the concept of marriage kafaah is an old tradition and already obsolete. Kafaah derived from the arabic word $k u f u$, which means equal, is the concept that sayyidah must marry only with sayyid. What is important right now, as he stated, if his daughter want to marry with someone, she has to get a Moøslem. ñIn Karimunjawa, if sayyidah want to wait for sayyid, her hair will become gray they will not see even her hair is gray,ò he said. Similarly, his son, Bastaan Banani got a native Irian Moslem wife.

Being known as an elder of Arabs in Karimunjawa, Sayyid Abdurrahman is well-known by the locals as the orang pintar (healer). Once upon a time a child of HajiAdib, a trader from Bawu, Jepara suffering from dengue fever that difficult to cure. Sayyid Abdurrahman
Comment [WU7]: I am not sure of my translation of the sentence, Pak. So, let you fixed it once more. 
gave water to the child a water with special prayers, and magically it healed. A similar incident occurred in Juwana, Pati. A fisherman named Sumar who lost his motorcycle, suddenly returned directly by the thieves after a certain reading given by Sayyid Abdurrahman. Other interesting stories associated with her best friend named Subur (Mbah Subur) from Juwana which is his a-friend who has a álark pastô He wanted to change his name into Muhammad Sowo. ñYou mock the prophet huh? Sowo? Thatôs a name of snake. Change to Soleh, Muhammad Solehò, said Sayyid Abdurrahman. By the time Mbah Subur then known as Mbah Soleh.

The emergence of Sayyid Abdurrahman as one of the figures in Karimunjawa began when Majelis AlKhidmah from Jepara entered Karimunjawa. Majelis Al-Khidmah are assemblies recitation of Tarekat Qadiriyah wa Naqsyabandiyah which has been active since the 1970s under the guidance of two leading of mursyid (grand master), namely K.H. Muhammad Uthman Al-Ishaqi and K.H. Ahmad Asrori Al-Ishaqi. Thatô why this tarekat also called Qadiriyah wa Naqsyabandiyah-Utsmaniah, both of them are father and son. During the leadership of K.H. Ahmad Asrori AlIshaqi Majelis Al-Khidmah has been increased rapidly. Pesantren AlFithrah in Kedinding Surabaya at the same time became the center of its activities followed by Tarekat Qadiriyah wa Naqsyabdiyyah. It made K.H. Ahmad Asrori Al-Ishaqi as an important tarekat (Islamic order) figure in Indonesia. As a large organization, the Majelis Al-Khidmah has some branches in various districts and cities in Indonesia, one of them were in Jepara under K.H. Mudzaffar.

Since 2008 the existence of Majelis Al-Khidmah in Karimunjawa has been established. Since its presence, Majelis Al-Khidmah actively held istighatsah, mujahadah, yasin, tahlil, and conducting routine activities containing maulidurrasul by readings poems of the historical of Prophet Muhammad Pbuh. The participants attended by hundreds of pilgrims who came from Jepara, Kudus, Semarang, and even East Java. K.H. Abdul Muôn, the religious leader in Karimunjawa, said that he was happy with the presence of Majelis AlKhidmah considering these assemblies have the same vision, developing Ahlussunnah wal Jamaah. That activities can be a fortress of faith communities to adverse negative effects of tourism influence in Karimunjawa, based on the name of Al- Khidmah which is to serve and not be served (Interview with K.H. Abdul Muôn, June 5th 2013).

Interestingly notes that the high esteem builders of Majelis AlKhidmah against the sayyid (the Alawiyyin). It seems to be followed by all branchs/ followers of Tarekat Qadiriyah wa NaqsyabandiyahUtsmaniyah. The leaders in every branch seeking information about sayyid (Habib) in their area. They believed that respecting dzuriyatul rasul (prophet descent) as well as respecting the Prophet Pbuh. It made K.H. Mudzaffar, the branch leader, encourage Sayyid Abdurrahman to join and participate in any activities of Majelis Al-Khidmah in Karimunjawa. ñwhether he can recite the Quran or not, even he only sit around when celebrating the activities, or even he 
HUMANIKA Vol. 19 No. 1 (2014) ISSN 1412-9418

Hadrami Diaspora In Karimunjawa

Rabith Jihan Amaruli

does not doing something, it will be alright,ò said K.H. Mudzaffar narrated by Sayyid Abdurrahman. Each activity of Majelis Al-Khidmah in Karimunjawa certainly involved Sayyid Abdurrahman to lead the prayers. In terms of respecting sayyid Majelis Al-Khidmah also plans to celebrate an event of Sayyid Abdurrahmanôs father (Sayyid Muhammad Al-Hamid) memorial Haul in every month of Rajab (Israô miôajMiôaj)

Sayyid Abdurrahman admits that he is not a member of Majelis AlKhidmah. He is also not a follower of Tarekat Qadiriyah wa Naqsyabandiyah . ก̃I am not a kiai (ulama), I am also not happy to be revered. What for? for Karimenjawa people hHabib and sayyid doe not use -anymore in Karimunjawa,ò he said. He felt that the presence of sayyid in Karimunjawa are not well received (Interview with Sayyid Abdurrahman, June 2nd 2013). According to him, this is the reason to understand the sayyid position among in Karimunjawa people which is different from Javanese people generally. Nowadays Karimunjawa people consider that sayyid as same as other ethnic groups. For them a respect must be addressed to anyone as human being whether he is sayyid or not (Interview with K.H. Abdul Muôn, June 5th 2013; interview with Martoyo, June 4th 2013). Surprisingly,

I it is consider to the majority believes of the Karimunjawa people which are

MoslemMtoesleaim, traditionally they are very respective to. Perhaps, the position of Arabs represented by Sayyid Abdurrahman is less among local religious leaders due to economic limitations access. To support his | family, Sayyid Abdurrahman run seaweed business. Every process of the business executed by himself, cultivation, planting, until packaging process run alone. $\mathrm{He}$ sells his products by IDR 5,000 to 10,000 per pack. Earlier, Sayyid Abdurrahman also sells dry fishes and beads business but all of them are failed.

The integration of Hadrami in Karimunjawa can happen easily. The assimilation process which is conducted by Sayyid Muhammad-by marryingied indigenous women as $\underline{\text { is }}$ the only option of Hadrami to survive and produced hybrid generations (muwallad). It is This option of marrying native women is -also followed by Sayyid Abdurrahman. In fact, in the context of assimilation Sayyid Abdurrahman is more open to provide flexibility for their daughters to married by natives. The efforts preserving Hadrami identity as viewed from Sayyid Abdurrahman to retain the title sayyid for him and his son, Faisaluddin.

\section{CONCLUSION}

From the discussion above indicated that in the early 20th century Hadrami diaspora in Karimunjawa in was purely motivated by economic reasons-especially in the early 20 th They lived by working as laborers to the Chinese. Economic limited access cause Karimunjawa Hadrami is not play an important role both economic and religion. It is caused by the economic condition of Hadrami in Karimunjawa which are not a wealthy merchant, like their predecessors. They do not necessarily establish an Arab colony in Karimunjawa. They are not inhabited
Formatted: Indonesian (Indonesia)

Formatted: Indonesian (Indonesia) 
HUMANIKA Vol. 19 No. 1 (2014) ISSN 1412-9418

Hadrami Diaspora In Karimunjawa

Rabith Jihan Amaruli

in specific environments such as in Pekalongan and Semarang.

In the one hand, economic conditions caused the composition number of Hadrami in Karimunjawa, shrink after their migration to Java, while in the other hand it led to a small group that still survive in Karimunjawa. They have been proved as a nation of immigrants known tough and accomplished, by performing various economic adaptations for survive, while maintaining their existence. It is one the efforts to retain their identity through naming Arabs and giving Islamic education for their children. The inclusion of a habib or sayyid titles can also be understood in this context of maintaining their identity.

Having a survival-, Arabs in Karimunjawa do inter-marriages (sayyid and non-sayyid) although it has own consequences, for example when sayyidah marry with non-sayyid, the sayyid clan lineage will be lost. The woman will not be able to pass sayyid lineage. In the context of social integration, it seems to be a significant of their contribution. As a result, the presence of Arabs in Karimunjawa coloured by multiethnic society. Changing status of the Arabs in Karimunjawa appears when Sayyid Abdurrahman to be a new icon of Majelis Al-Khidmah, a teaching institution based in Surabaya, which has branches in many parts of Indonesia.

\section{REFERENCES}

Abushouk, Ahmed Ibrahim and Hassan Ahmed Ibrahim, et. al.
(2009). The Hadrami Diaspora:

Identity Maintenance or Assimilation? Leiden, Boston: BRILL.

Badan Pusat Statistik Kabupaten Jepara. (2011).

Balai Taman Nasional Karimunjawa. (2009) Survei Sosial Ekonomi Kepulauan Karimunjawa. Semarang: Balai Taman Nasional Karimunjawa-Dirjen Perlindung-an Hutan dan Konservasi Alam-Departemen Kehutanan.

Dian Vitriana, ñPeranan Silsilah dalam Sistem Kekeluargaan Peranakan Arab di Semarang Tahun 19341944ò (Thesis Department of History, Faculty of Letters, Diponegoro University, 1987).

http://ahlulbait.blogdetik.com/2009/01 /22/marga-al-hamid-3/, (19 July 2013).

John Roosa and Ayu Ratih, ñSejarah Lisan di Indonesia dan Kajian Subjektivitasò in Henk Schulte Nordholt, et. al. (2008). Perspektif Baru Penulisan Sejarah Indonesia. Jakarta: Yayasan Obor Indonesia dan KITLV-Jakarta.

Karimunjawa dalam Angka. (2012).

van den Berg, L.W.C. (2010). Orang Arab di Nusantara. Translated by Komunitas Bambu (Jakarta: Komunitas Bambu. 
HUMANIKA Vol. 19 No. 1 (2014) ISSN 1412-9418

Hadrami Diaspora In Karimunjawa

Rabith Jihan Amaruli

Manger, Leif O. (2010). The Hadrami

Diaspora: Community-Building on the Indian Ocean rim. London: Berghan Books.

Monografi Desa Karimunjawa. (2012).

Paul Thompson. (2012). Suara dari Masa Silam: Teori dan Metode Sejarah Lisan. Translated by Ombak. Penerbit Ombak: Yogyakarta.

Profil Kecamatan Karimunjawa Tahun 2012.

Yatin Suwarno, et. al. (2010). Identifikasi Geososial Unk untuk Mendukung Ketahanan Pangan Di-di Taman Nasional Karimun-jawa Balai Penelitian Geomatika Bakosurtanal.
Interview with K.H. Abdul Muôn, June 5th 2013.

Interview with Andi Bugis, June 6th 2012.

Interview with Arif, June 3rd 2013.

Interview with Asrini, June 4th 2013.

Interview with H.M. Yuslam Said, June 6th 2012.

Interview with Sayyid Abdurrahman, June 2nd 2013.

Interview with Martoyo, June 4th-5th 2013.

Interview with Pdt. Matius Slamet, June 4th 2013.

Interview with Sutrimo, June 5th 2012. 